\title{
Triterpenoids from The Bark of Garcinia porecta and their Cytotoxic Activity against MCF7 Breast Cancer Lines
}

\author{
Darwati Darwati $^{\mathrm{a}}$, Alya Tsamrotul ${ }^{\mathrm{a}}$, Tati Herlina ${ }^{\mathrm{a}}$, Tri Mayantia, Nurlelasari \\ Nurlelasari $^{\mathrm{a}}$, Kansy Haikal ${ }^{\mathrm{b}}$, Unang Supratman ${ }^{\mathrm{a}, \mathrm{b}^{*}}$ \\ ${ }^{a}$ Department of Chemistry, Faculty of Mathematics and Natural Sciences, Universitas Padjadjaran, \\ Jatinangor 45363, Sumedang, Indonesia \\ ${ }^{b}$ Central Laboratory, Universitas Padjadjaran, Jatinangor 45363, Sumedang, Indonesia \\ * Corresponding author \\ E-mail: unang.supratman@unpad.ac.id
}

DOI: 10.20961/alchemy.15.1.20262.1-9

Received 12 April 2018, Accepted 29 October 2018, Published Online 01 March 2019

\begin{abstract}
The Garcinia genus is a well known tropical plant in the Indo-Malesiana region and mainly distributed in tropical countries including Indonesia, Thailand, and Malaysia. Previous phytochemical studies on Garcinia species have led to the identification and isolation of mainly prenylated xanthones. This research describes the isolation and structure elucidation of isolated triterpenoids compounds from the bark of Garcinia porecta. Dried powder bark of G. porecta was extracted with methanol and then partitioned with $n$-hexane, ethyl acetate, and $n$-butanol. The $n$-hexane extract then was separated and purified with chromatography techniques to obtain isolated compounds $\mathbf{1}$ and $\mathbf{2}$. The chemical structure of isolated compounds were elucidated by spectroscopic methods including one and two-dimensional NMR as well as high-resolution mass spectrometric analysis and identified as lanosterol (1) dan arabidiol (2), respectively. These triterpenoids were isolated from this plant for the first time. Compound $\mathbf{1}$ and $\mathbf{2}$ showed weak cytotoxic activity against MCF-7 breast cancer cells with $\mathrm{IC}_{50}$ values of 60.09 dan $46.17 \mu \mathrm{M}$, respectively.
\end{abstract}

Keywords: arabidiol, Garcinia porecta, lanosterol, MCF7 breast cancer cells, triterpenoid.

\section{INTRODUCTION}

Garcinia is one genus in the family Guttiferae with number of species and is distributed in lowland forests of tropical Asia, Africa, Polynesia and New Caledonia (Merza et al., 2004; Heyne, 1982). In Indonesia about 91 species spread across the island of Sumatra, Java, Sulawesi, and Maluku (Panthong et al., 2006) and known for prenylated xanthone content (Ampofo and Waterman, 1986; Bennet and Lee, 1989; Adegboye, 2008). The previous investigation on Garcinia species had reported a wide range of biological activities such as cytotoxic, antimicrobial, antimalarial, and anti-HIV-1 protease inhibitory (Kosela et 
al., 2000; Bennet and Lee, 1989). In our ongoing research to get new compounds from Garcinia species, we selected Garcinia porecta. G.porecta commonly known as "manggisutan" in Indonesia and widely distributed in tropical countries especially in Indonesia and Malaysia (Martin, 1980). In this report, we discuss the isolation and structural identification of two known triterpenoids, lanosterol (1) and arabidiol (2) from the methanol extract of the bark of G. porecta. Cytotoxicity against MCF7 breast cancer lines was evaluated for all isolated compounds.

\section{METHODS}

\section{General Procedure}

The melting points were measured on an electro thermal melting point equipment and uncorrected. The IR spectra were obtained on 1760X Perkin-Elmer using KBr discs. The HRTOFMS were obtained using a Waters Xevo QTOF MS mass spectrometer. NMR spectra were recorded on JEOL JNM A-500 spectrometer (500 MHz for ${ }^{1} \mathrm{H}$ and $125 \mathrm{MHz}$ for ${ }^{13} \mathrm{C}$ ) and TMS as an internal standard. Column chromatography was performed with silica gel 60 (70-230 and 200-400 mesh). Vacuum Liquid Chromatography on silica gel ( $\mathrm{SiO}_{2}$, Kieselgel 60, Merck, Darmstadt, Germany), Column chromatography on silica gel ( $\mathrm{SiO}_{2}$, Kieselgel 60, Merck, Darmstadt, Germany), TLC analysis on Kieselgel $60 \mathrm{~F}_{254}$ (Merck) plates; visualization was performed with UV lamp and plates were sprayed with $10 \% \mathrm{H}_{2} \mathrm{SO}_{4}$ solution in ethanol and heated.

\section{Plant Material}

The bark of G. porecta was obtained from Bogor Botanical Garden, Bogor, Indonesia in June 2017. The plant was provided by Bogoriense Herbarium, and a voucher specimen was deposited at the herbarium.

\section{Extraction and Isolation}

The powder dried bark $(2.0 \mathrm{Kg})$ of $G$. porecta was extracted with aqueous methanol $(12 \mathrm{~L})$ at room temperature. Evaporation of the methanolic extract to produce the brown residue (150.4 g). The residue was first suspended in $\mathrm{H}_{2} \mathrm{O}$ and then partitioned successively with $n$-hexane, EtOAc, and $n$-butanol. The $n$-hexane extract $(20.0 \mathrm{~g})$ was separated by vacuum liquid chromatography on silica gel G60 using $n$-hexane-EtOAc as gradient solvent to give seven fractions (A-G). Fraction D (3.25 g) was separated on a column chromatography of silica gel, with an-hexane-acetone as solvent (10:0-1:1), to yield six subfractions (C01-C06). Subfraction C04 (185.5 mg) was chromatographed on a column of silica gel with $\mathrm{CHCl}_{3}$ : $\mathrm{MeOH}(9.75: 0.25)$ as a solvent to give five subfractions (C04A- 
C04E). Subfraction C04B (86.5 mg) was separated on preparative TLC of silica gel $\mathrm{GF}_{254}$, with $n$-hexane-EtOAc (9:1) as a solvent, to produce 1 (18.5 mg). Fraction E (2.10 g) was separated on a column chromatography of silica gel with a gradient of $n$-hexane-acetone (10:1-1:10) as a solvent, to yield five subfractions (D01-D05). Subfraction D03(78.5 mg) was recrystallized in $\mathrm{MeOH}$, to give $2(12.6 \mathrm{mg})$.

\section{Bioassays for cytotoxic activity}

Determination of the cytotoxic activities was conducted according to the methodology described in previous papers (Supriatno et al., 2018). The MCF-7 cells were seeded into 96-well plates at an initial cell density of $3 \times 10^{4}$ cells $\mathrm{cm}^{-3}$. After 24 hours of incubation, varying concentrations of samples were added. The compounds added were first dissolved in DMSO at the required concentration. Then six desirable concentrations were prepared using PBS (phosphoric buffer solution, $\mathrm{pH}=7.30$ - 7.65). Control wells received only DMSO. The assay was terminated after a 48 hours incubation period by adding MTT reagent [3-(4,5-dimethylthiazol-2-yl)-2,5-diphenyl tetrazolium bromide]. The incubation was continued for another 4 hours, in which the MTT-stop solution containing SDS (sodium dodecyl sulphate) was added and another 24 hours incubation was conducted. Optical density was read by using a microplate reader at $550 \mathrm{~nm}$. $\mathrm{IC}_{50}$ values were taken from the plotted graph of percentage live cells compared to control (\%), receiving only PBS and DMSO, versus the tested concentration of compounds $(\mu \mathrm{M})$. The $\mathrm{IC}_{50}$ value is the concentration required for $50 \%$ growth inhibition. Each assay and analysis run in triplicate and averaged.

\section{RESULT AND DISCUSSION}

The methanolic extract from the bark of $C$. porecta was concentrated and extracted with $n$-hexane, ethyl acetate, and $n$-butanol. The $n$-hexane extract showed the strongest cytotoxic activity against MCF7 breast cancer cells with an $\mathrm{IC}_{50} 35 \mu \mathrm{g} / \mathrm{mL}$ compared with ethyl acetate and $n$-butanol extract with showed an $\mathrm{IC}_{50}$ of 48 and $52 \mu \mathrm{g} / \mathrm{mL}$, respectively. By using cytotoxic activity assay, the $n$-hexane extract was separated by column chromatography on silica gel G60 and preparative Thin Layer Chromatography (TLC) on silica gel $\mathrm{GF}_{254}$ to produce two cytotoxic compounds $\mathbf{1}$ and $\mathbf{2}$ (Figure 1).

Lanosterol (1). White needle crystals; m.p. 139-140 ${ }^{\circ} \mathrm{C}$; IR (KBr) $v_{\max }\left(\mathrm{cm}^{-1}\right) 3360$, 2980, 2860, 1580 and 1156; ${ }^{1} \mathrm{H}-\mathrm{NMR}\left(\mathrm{CDCl}_{3}, 500 \mathrm{MHz}\right)$ and ${ }^{13} \mathrm{C}-\mathrm{NMR}\left(\mathrm{CDCl}_{3}, 125 \mathrm{MHz}\right)$, see Table 1; MS spectrum $m / z 426$. 
Arabidiol (2). White needle crystals; m.p. 147-149 ${ }^{\circ} \mathrm{C}$; IR (KBr) $v_{\max }\left(\mathrm{cm}^{-1}\right) 3350$, 1555, 1140, and 1045; ${ }^{1} \mathrm{H}-\mathrm{NMR}\left(\mathrm{CDCl}_{3}, 500 \mathrm{MHz}\right)$ and ${ }^{13} \mathrm{C}-\mathrm{NMR}\left(\mathrm{CDCl}_{3}, 125 \mathrm{MHz}\right)$, see Table 1; MS spectrum $m / z, 444$.

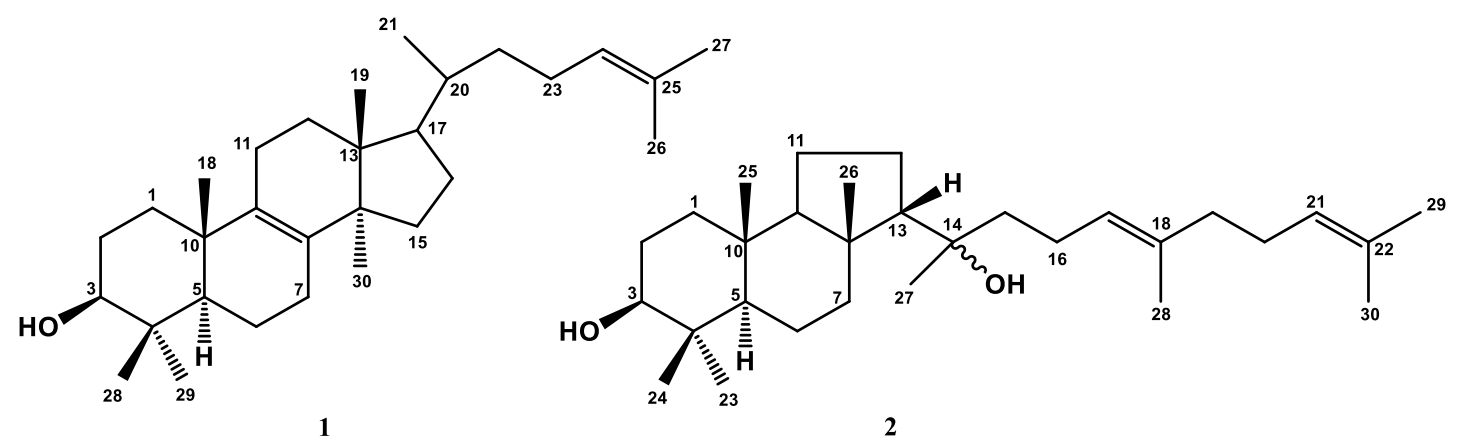

Figure 1. Chemical Structures of 1 and 2.

Compound 1 was isolated as a white needle crystal. The molecular formula was established to be $\mathrm{C}_{30} \mathrm{H}_{50} \mathrm{O}$ based on MS spectrum $\mathrm{m} / \mathrm{z}, 426$ and NMR data (Table 1), indicating unsaturation number of six. The IR spectra revealed peaks at 3360, 2980, 2860, 1580 and $1156 \mathrm{~cm}^{-1}$ due to of hydroxyl, aliphatic, carbon-carbon double bond and ether groups. The ${ }^{1} \mathrm{H}-\mathrm{NMR}$ spectrum of the compound 1 revealed the presence of seven tertiary methyl resonances at $\delta_{\mathrm{H}} 0.89(3 \times), 1.01(2 \times), 1.70$ and 1.82 , one secondary methyl at $\delta_{\mathrm{H}}$ $0.88(3 \mathrm{H}, \mathrm{d}, J=5.6 \mathrm{~Hz})$, one elefinic methine proton at $\delta_{\mathrm{H}} 5.20(1 \mathrm{H}, \mathrm{dd}, J=3.4,7.2 \mathrm{~Hz})$, one oxygenated proton at $\delta_{\mathrm{H}} 3.34(1 \mathrm{H}, \mathrm{dd}, J=4.8,6.7 \mathrm{~Hz})$ and aliphatic protons resonance at $\delta_{\mathrm{H}}$ 1.00-2.00.The ${ }^{13} \mathrm{C}-\mathrm{NMR}$ spectrum revealed 30 carbon signals, which were determined $\mathrm{d}$ by their chemical shifts and the DEPT spectra as seven tertiary methyls, one secondary methyl, one $\mathrm{sp}^{2}$ methine, three $\mathrm{sp}^{2}$ quaternary carbons, one $\mathrm{sp}^{3}$ oxygenated methine, ten $\mathrm{sp}^{3}$ methylenes, three $\mathrm{sp}^{3}$ methines, and four $\mathrm{sp}^{3}$ quaternary carbons. These unsaturations accounted for two out of the total six degrees of unsaturation. The remaining four degrees of unsaturation were consistent with the lanostane-type triterpenoid (Susanti et al., 2013; Connolly and Hill, 2003). To determine the connectivity of the functional group in compound 1, ${ }^{1} \mathrm{H}-{ }^{1} \mathrm{H}$ COSY and HMBC experiments were conducted, and the results are shown in Figure 2. The ${ }^{1} \mathrm{H}-{ }^{1} \mathrm{H}$ COSY spectrum of 1 showed connectivity in $\mathrm{H}_{1}-\mathrm{H}_{2}-\mathrm{H}_{3}, \mathrm{H}_{5}-$ $\mathrm{H}_{6}-\mathrm{H}_{7}, \mathrm{H}_{11}-\mathrm{H}_{12}, \mathrm{H}_{15}-\mathrm{H}_{16}-\mathrm{H}_{17}$ and $\mathrm{H}_{20}-\mathrm{H}_{22}-\mathrm{H}_{23}-\mathrm{H}_{24}$, indicating the presence of lanostane-type (Connolly and Hill, 2003). In the HMBC spectrum, the connectivity arising from the tertiary methyl protons to their attached carbons enabled the determine of the five primary methyls at C-4, C-10, C-14, C-15, and C-25, respectively. Then, a connectivity from an olefinic proton at $\mathrm{H}-24\left(\delta_{\mathrm{H}} 5.20\right)$ to $\mathrm{C}-25\left(\delta_{\mathrm{C}} 131.5\right)$ and $\mathrm{C}-24\left(\delta_{\mathrm{C}} 124.7\right)$ and connectivity from the methyl proton at $\mathrm{CH}_{3}-26\left(\delta_{\mathrm{H}} 1.70\right)$ and $\mathrm{CH}_{3}-27\left(\delta_{\mathrm{H}} 1.82\right)$ to $\mathrm{C}-25\left(\delta_{\mathrm{C}} 131.5\right)$ were used to 
determine a double bond at C-24/C-25. This observation was feature for a lanostane-type triterpenoid (Susanti et al., 2013; Connolly and Hill, 2003). The other olefinic moiety located at C-8/C-9 was supported by connectivity from $\mathrm{CH}_{3}-18\left(\delta_{\mathrm{H}} 1.01\right)$ to $\mathrm{C}-9\left(\delta_{\mathrm{C}} 134.5\right)$ and methylene proton at C-7 $\left(\delta_{\mathrm{H}} 1.99\right)$ to $\mathrm{C}-8\left(\delta_{\mathrm{C}} 135.2\right)$. The hydroxy group at C-3 was determined based on connectivity from $\mathrm{CH}_{3}-28\left(\delta_{\mathrm{H}} 0.89\right)$ and $\mathrm{H}-2\left(\delta_{\mathrm{H}} 1.72\right)$ to $\mathrm{C}-3\left(\delta_{\mathrm{C}} 78.7\right)$.

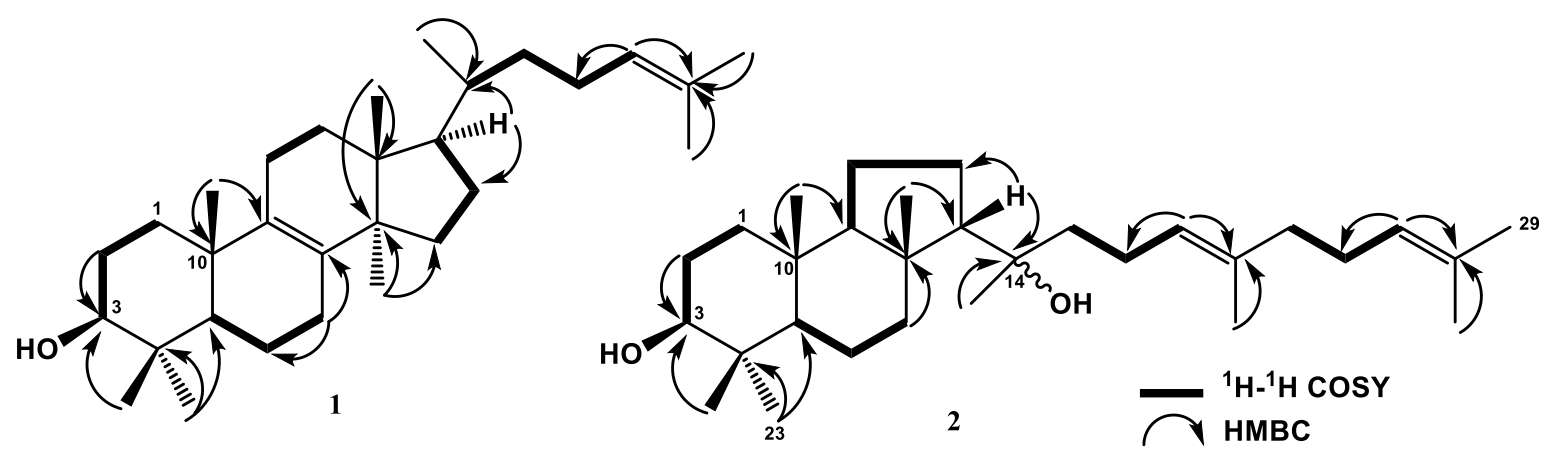

Figure 2. ${ }^{1} \mathrm{H}-{ }^{1} \mathrm{H}$ and $\mathrm{HMBC}$ Correlation of $\mathbf{1}$ and $\mathbf{2}$

The configuration of $\mathbf{1}$ was identified by comparison those coupling constant in ${ }^{1} \mathrm{H}$ NMR spectra $\left({ }^{1,2} \mathbf{J}\right.$ and $\left.{ }^{2,3} \mathrm{~J}\right)$ and chemical shift of ${ }^{13} \mathrm{C}$ NMR spectra with previous literature as well as from biogenetic point of view for occurrence of lanostane-type triterpenoid in Garcinia genus (Susanti et al., 2013; Connolly and Hill, 2003). A detailed comparison of the NMR data of 1 with those of lanosterol previously reported (Susanti et al., 2013) revealed very high similarity. Therefore, compound $\mathbf{1}$ was identified as lanosterol.

Compounds 2 was isolated as a white needle crystal. The chemical formula was established to be $\mathrm{C}_{30} \mathrm{H}_{52} \mathrm{O}_{2}$ based on MS spectrum m/z 444 and NMR data (Table 1), thus indicating the degree of unsaturation of five. The IR spectra revealed peaks at 3350, 2970, 2850,1590 and $1140 \mathrm{~cm}^{-1}$ due to of hydroxyl, aliphatic, the double bond and ether groups. The ${ }^{1} \mathrm{H}-\mathrm{NMR}$ spectrum revealed of eight tertiary methyl resonances at $\delta_{\mathrm{H}} 0.89,0.91,0.84$, $0.86,1.20,1.61,1.82$ and 1.70, one oxygenated methine at $\delta_{\mathrm{H}} 3.42(1 \mathrm{H}, \mathrm{dd}, J=4.7,6.2 \mathrm{~Hz})$, two elefinic methine protons at $\delta_{\mathrm{H}} 5.10(1 \mathrm{H}, \mathrm{dd}, J=3.4,7.2 \mathrm{~Hz})$ and $\delta_{\mathrm{H}} 5.20(1 \mathrm{H}, \mathrm{dd}, J=3.5$, $6.8 \mathrm{~Hz})$ as well as aliphatic protons resonance at $\delta_{\mathrm{H}} 1.00-2.00$. The ${ }^{13} \mathrm{C}-\mathrm{NMR}$ spectrum revealed 30 carbon signals, which were determined by their chemical shifts and the DEPT spectrum as eight tertiary methyls, two $\mathrm{sp}^{2}$ methine, two $\mathrm{sp}^{2}$ quaternary carbons, one $\mathrm{sp}^{3}$ oxygenated methine, one $\mathrm{sp}^{3}$ oxygenated carbon, ten $\mathrm{sp}^{3}$ methylenes, three $\mathrm{sp}^{3}$ methines, and three $\mathrm{sp}^{3}$ quaternary carbons. These unsaturations accounted for two out of the total five degrees of unsaturation. The remaining three degrees of unsaturation were consistent with the tricylic triterpenoid (Xiang et al., 2006; Connolly and Hill, 2003). To determine the connectivity of the functional group in compound $2,{ }^{1} \mathrm{H}-{ }^{1} \mathrm{H}$ COSY and HMBC experiments 
were conducted, and the results are shown in Figure 2. The ${ }^{1} \mathrm{H}-{ }^{1} \mathrm{H}$ COSY spectra of $\mathbf{2}$ showed connectivity in $\mathrm{H}_{1}-\mathrm{H}_{2}-\mathrm{H}_{3}, \mathrm{H}_{5}-\mathrm{H}_{6}-\mathrm{H}_{7}, \mathrm{H}_{9}-\mathrm{H}_{11}-\mathrm{H}_{12}-\mathrm{H}_{13}, \mathrm{H}_{15}-\mathrm{H}_{16}-\mathrm{H}_{17}$, and $\mathrm{H}_{19}-\mathrm{H}_{20}-\mathrm{H}_{21}$, indicating the presence of tricylic triterpenoid (Xiang et al., 2006; Connolly and Hill, 2003). The correlations arising from the tertiary methyl protons to their neighboring carbons enabled the determine five methyls at C-4, C-8, C-10, C-14, C-18, and C-25, respectively.

In addition, a correlation from one olefinic proton at $\mathrm{H}-21\left(\delta_{\mathrm{H}} 5.10\right)$ to $\mathrm{C}-25\left(\delta_{\mathrm{C}} 132.0\right)$ and $\mathrm{C}-24\left(\delta_{\mathrm{C}} 26,4\right)$, and another olefinic proton at $\mathrm{H}-17\left(\delta_{\mathrm{H}} 5.20\right)$ to $\mathrm{C}-18\left(\delta_{\mathrm{C}} 135.0\right)$ and $\mathrm{C}-$ $16\left(\delta_{\mathrm{C}} 22.8\right)$ were used to determine a double bond at C-24/C-25 and C-17/C-18, which was characteristic for a arabidiol-type triterpenoid (Xiang et al., 2006; Connolly and Hill, 2003). The hydroxyl group at C-3 was determined based on the correlation from $\mathrm{CH}_{3}-24\left(\delta_{\mathrm{H}} 0.89\right)$ and $\mathrm{H}-2\left(\delta_{\mathrm{H}} 1.72\right)$ to $\mathrm{C}-3\left(\delta_{\mathrm{C}} 78.7\right)$.The other hydroxy group was located at C-14 by correlations from $\mathrm{CH}_{3}-27\left(\delta_{\mathrm{H}} 1.20\right), \mathrm{H}-13\left(\delta_{\mathrm{H}} 1.10\right)$ and $\mathrm{H}-15\left(\delta_{\mathrm{H}} 1.40\right)$ to $\mathrm{C}-14\left(\delta_{\mathrm{C}} 75.3\right)$. A comparison of the NMR data of $\mathbf{2}$ with those of arabidiol previously reported (Xiang et al., 2006), revealed the high similarity. Therefore compound $\mathbf{2}$ was identified as an arabidiol.

The cytotoxic activity of compounds $1(60.09 \mathrm{mM})$ and $\mathbf{2}(46.17 \mu \mathrm{M})$ were evaluated against the against MCF-7 breast cancer cells according to a method described (Supriatno et al., 2018) and was used a cisplatin ( $\mathrm{IC}_{50} 27.0 \mu \mathrm{M}$ ) as a positive control (Hadisaputri et al., 2012). Based on the $\mathrm{IC}_{50}$ value of compounds 2 showed stronger activity, suggesting that the presence of an additional hydroxyl group at C-14 and opening of D-ring of triterpenoid structure seems to increase the cytotoxic activity. These results are similar to those of previously reported that the presence of additional of the hydroxyl group and the opening of D-ring in flavonoid structure can increase the cytotoxic activity (Boussahel et al., 2015).

Table 1. NMR data for Compounds 1 and 2

\begin{tabular}{|c|c|c|c|c|}
\hline \multirow[b]{2}{*}{$\begin{array}{l}\text { Position of } \\
\text { C }\end{array}$} & \multicolumn{2}{|l|}{$1 *$} & \multicolumn{2}{|l|}{$2 * *$} \\
\hline & 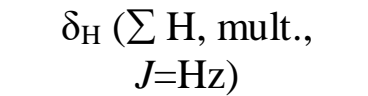 & $\begin{array}{c}\delta_{\mathrm{C}} \\
\text { (mult.) }\end{array}$ & $\delta_{\mathrm{H}}\left(\sum_{J=\mathrm{Hz})}^{\mathrm{H}, \text { mult. }}\right.$ & $\begin{array}{c}\delta_{\mathrm{C}} \\
\text { (mult.) }\end{array}$ \\
\hline \multirow[t]{2}{*}{1} & $1.67(1 \mathrm{H}, \mathrm{m})$ & $35.6(\mathrm{t})$ & $1.56(1 \mathrm{H}, \mathrm{m})$ & $38.4(\mathrm{t})$ \\
\hline & $1.42(1 \mathrm{H}, \mathrm{m})$ & & $1.31(1 \mathrm{H}, \mathrm{m})$ & \\
\hline \multirow[t]{2}{*}{2} & $1.72(1 \mathrm{H}, \mathrm{m})$ & $27.5(\mathrm{t})$ & $1.72(1 \mathrm{H}, \mathrm{m})$ & $27.4(\mathrm{t})$ \\
\hline & $1.47(1 \mathrm{H}, \mathrm{m})$ & & $1.46(1 \mathrm{H}, \mathrm{m})$ & \\
\hline 3 & $\begin{array}{l}3.34(1 \mathrm{H}, \mathrm{dd}, 4.8, \\
6.7)\end{array}$ & $78.7(d)$ & $3.42(1 \mathrm{H}, \mathrm{dd}, 4.5,6.4)$ & $78.6(d)$ \\
\hline 4 & - & $38.9(\mathrm{~s})$ & - & $38.8(\mathrm{~s})$ \\
\hline 5 & $1.07(1 \mathrm{H}, \mathrm{m})$ & $38.7(d)$ & $0.94(1 \mathrm{H}, \mathrm{m})$ & $55.3(d)$ \\
\hline \multirow[t]{2}{*}{6} & $1.60(1 \mathrm{H}, \mathrm{m})$ & $19.6(t)$ & $1.63(1 \mathrm{H}, \mathrm{m})$ & $18.2(\mathrm{t})$ \\
\hline & $1.36(1 \mathrm{H}, \mathrm{m})$ & & $1.38(1 \mathrm{H}, \mathrm{m})$ & \\
\hline \multirow[t]{2}{*}{7} & $1.99(1 \mathrm{H}, \mathrm{m})$ & $26.5(\mathrm{t})$ & $1.56(1 \mathrm{H}, \mathrm{m})$ & $40.3(\mathrm{t})$ \\
\hline & $1.89(1 \mathrm{H}, \mathrm{m})$ & & $1.31(1 \mathrm{H}, \mathrm{m})$ & \\
\hline 8 & - & $135.2(\mathrm{~s})$ & - & $35.2(\mathrm{~s})$ \\
\hline
\end{tabular}


Table 1. NMR data for Compounds 1 and 2 (continued)

\begin{tabular}{|c|c|c|c|c|}
\hline \multirow[b]{2}{*}{$\begin{array}{c}\text { Position of } \\
\text { C }\end{array}$} & \multicolumn{2}{|l|}{$1 *$} & \multicolumn{2}{|l|}{$2 * *$} \\
\hline & 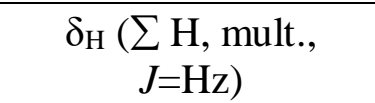 & $\begin{array}{c}\delta_{\mathrm{C}} \\
\text { (mult.) }\end{array}$ & $\delta_{\mathrm{H}}\left(\sum_{J=\mathrm{Hz}} \mathrm{H}, \mathrm{mult}\right.$. & $\begin{array}{c}\delta_{\mathrm{C}} \\
\text { (mult.) }\end{array}$ \\
\hline 9 & 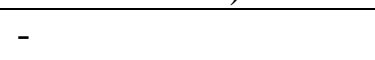 & $134.5(\mathrm{~s})$ & $0.94(1 \mathrm{H}, \mathrm{m})$ & 58.9 (d) \\
\hline 10 & - & $37.3(\mathrm{~s})$ & - & $38.2(\mathrm{~s})$ \\
\hline 11 & $1.98(1 \mathrm{H}, \mathrm{m})$ & $21.9(\mathrm{t})$ & $1.90(1 \mathrm{H}, \mathrm{m})$ & $20.4(\mathrm{t})$ \\
\hline & $1.89(1 \mathrm{H}, \mathrm{m})$ & & $1.65(1 \mathrm{H}, \mathrm{m})$ & \\
\hline 12 & $\begin{array}{l}1.66(1 \mathrm{H}, \mathrm{m}) \\
1.42(1 \mathrm{H}, \mathrm{m})\end{array}$ & $35.6(t)$ & $\begin{array}{l}1.86(1 \mathrm{H}, \mathrm{m}) \\
1.60(1 \mathrm{H}, \mathrm{m})\end{array}$ & $25.1(\mathrm{t})$ \\
\hline 13 & - & $44.6(\mathrm{~s})$ & $1.10(1 \mathrm{H}, \mathrm{m})$ & $57.8(\mathrm{~d})$ \\
\hline 14 & - & $49.9(\mathrm{~s})$ & - & $75.3(\mathrm{~s})$ \\
\hline 15 & $1.42(1 \mathrm{H}, \mathrm{m})$ & $35.1(\mathrm{t})$ & $1.40(2 \mathrm{H}, \mathrm{m})$ & $44.3(\mathrm{t})$ \\
\hline & $1.17(1 \mathrm{H}, \mathrm{m})$ & & & $22.8(\mathrm{t})$ \\
\hline 16 & $\begin{array}{l}1.90(1 \mathrm{H}, \mathrm{m}) \\
1.65(1 \mathrm{H}, \mathrm{m})\end{array}$ & $28.5(\mathrm{t})$ & $1.94(2 \mathrm{H}, \mathrm{m})$ & \\
\hline 17 & $1.15(1 \mathrm{H}, \mathrm{m})$ & $50.5(d)$ & $5.10(1 \mathrm{H}, \mathrm{dd}, 3.4,7.2)$ & $124.7(d)$ \\
\hline 18 & $1.01(3 \mathrm{H}, \mathrm{s})$ & $19.8(\mathrm{q})$ & - & $135.0(\mathrm{~s})$ \\
\hline 19 & $0.89(3 \mathrm{H}, \mathrm{s})$ & $16.7(\mathrm{q})$ & $1.98(2 \mathrm{H}, \mathrm{t}, 7.2)$ & $39.7(\mathrm{t})$ \\
\hline 20 & $\begin{array}{l}1.32 \\
5.6)\end{array}(1 \mathrm{H}, \mathrm{dd}, 2.6$ & $30.3(d)$ & $2.00(2 \mathrm{H}, \mathrm{t}, 7.2)$ & $26.4(\mathrm{t})$ \\
\hline 21 & $0.88(1 \mathrm{H}, \mathrm{d}, 5.6)$ & $19.5(q)$ & $5.20(1 \mathrm{H}, \mathrm{dd}, 3.5,6.8)$ & $123.5(d)$ \\
\hline 22 & $1.53(2 \mathrm{H}, \mathrm{m})$ & $36.4(\mathrm{t})$ & - & $132.0(\mathrm{~s})$ \\
\hline 23 & $1.94(2 \mathrm{H}, \mathrm{m})$ & $24.7(\mathrm{t})$ & $0.89(3 \mathrm{H}, \mathrm{s})$ & $22.4(q)$ \\
\hline 24 & $\begin{array}{l}5.20 \\
7.2)\end{array}(1 \mathrm{H}, \mathrm{dd}, \quad 3.4$ & $124.7(d)$ & $0.91(3 \mathrm{H}, \mathrm{s})$ & $23.4(\mathrm{q})$ \\
\hline 25 & - & $131.5(\mathrm{~s})$ & $0.84(3 \mathrm{H}, \mathrm{s})$ & $16.1(q)$ \\
\hline 26 & $1.70(3 \mathrm{H}, \mathrm{s})$ & $18.6(q)$ & $0.86(3 \mathrm{H}, \mathrm{s})$ & $15.8(q)$ \\
\hline 27 & $1.82(3 \mathrm{H}, \mathrm{s})$ & $10.6(q)$ & $1.20(3 \mathrm{H}, \mathrm{s})$ & $26.1(\mathrm{q})$ \\
\hline 28 & $1.01(3 \mathrm{H}, \mathrm{s})$ & $25.0(\mathrm{q})$ & $1.61(3 \mathrm{H}, \mathrm{s})$ & $16.1(\mathrm{q})$ \\
\hline 29 & $0.89(3 \mathrm{H}, \mathrm{s})$ & $23.5(\mathrm{q})$ & $1.82(3 \mathrm{H}, \mathrm{s})$ & $18.6(\mathrm{q})$ \\
\hline 30 & $0.89(3 \mathrm{H}, \mathrm{s})$ & $20.4(q)$ & $1.70(3 \mathrm{H}, \mathrm{s})$ & $24.6(q)$ \\
\hline
\end{tabular}

\section{CONCLUSIONS}

Two known triterpenoids, lanosterol (1) and arabidiol (2) were obtained from the bark of Garcinia poreccta. Compounds $\mathbf{1}$ and $\mathbf{2}$ showed weak cytotoxic activity against MCF-7 breast cancer cells with $\mathrm{IC}_{50}$ values of 25.6 and $20.8 \mu \mathrm{M}$, respectively, indicating the presence of an additional hydroxyl group at C-14; and the opening of D-ring of triterpenoid structure seems to increase the cytotoxic activity. 


\section{ACKNOWLEDGEMENTS}

This research was financially supported by Universitas Padjadjaran, Indonesia (Hibah Internal UNPAD, 2017). We thank Dr. Yuni Elsa at Central Laboratory, Universitas Padjadjaran for cytotoxicity bioassay.

\section{REFERENCES}

Adegboye, M.F., Akinpelu, D.A., and Okoh, A.L., 2008. The bioactive and phytochemical properties of Garcinia kola (Heckel) seed extract on some pathogens. Africal Journal of Biotechnology 7, 3934-3938.

Ampofo, S.A., and Waterman, P.G., 1986. Xanthones from tree Garcinia species. Phytochemistry 25, 2351-2355. DOI:10.1016/S0031-9422(00)81694-5.

Bennet, G.J., and Lee, H.H., 1989. Xanthones from Guttiferae, Phytochemistry 28, 967. DOI: 10.1016/0031-9422(89)80170-0.

Boussahel, S., Speciale, A., Dahamna, S., Amar, Y., Bonaccorsi, I., Cacciola,F., Cimino, F., Donato, P., Ferlazzo, G., Harzallah, D., Cristani, M., 2015. Flavonoid profile, antioxidant and cytotoxic activity of different extracts from Algerian Rhamnus alaternus L. bark. Pharmacognosy Magazine 11(1): 102-S109. DOI: 10.4103/09731296.157707.

Connolly, J.D., and Hill, R.A. 2003. Triterpenoids. Natural Products Report 20, 640-65. DOI: $10.1039 / \mathrm{b} 204068 \mathrm{a}$.

Hadisaputri, Y.E., Pharm. D., Miyazaki, T., Suzuki, S., Yokobori, T., Kobayashi, T., Tanaka, N., Inose, T., Sohda, M and Kuwano, H., 2012. TNFAIP8 Overexpression: Clinical Relevance to Esophageal Squamous Cell Carcinoma. Annals of Surgical Oncology 19, S589-S596. DOI: 10.1245/s10434-011-2097-1.

Heyne, K., 1982. The Useful Indonesian Plants, Research and Development Agency. Ministry of Forestry, Jakarta, Indonesia.

Kosela, S., Hu, L.H., Rachmatia, T., Hanafi, M., and Sim, K.Y., 2000. Dulxanthones F-H, three new pyranoxanthones from Garcinia dulcis. Journal of Natural Products 63(3): 406-407. DOI: 0.1021/np990397o.

Martin, F.W., Durian and Mangosteen., 1980. Dalam Nagy, S., and Shaw, D.E., Tropical and Subtropical Fruits: Composition, Properties and Uses; Eds.: AVI Publishing; Westport, CT; pp 407-414.

Merza, J., Aumond, M.C., Rondeau, D., Dumontet, V., Le Ray., A.M., Seraphin, D., and Richomme, P., 2004. Prenylated Xanthones and Tocotrienols from Garcinia virgata. Phytochemistry 65, 2915-2920. DOI:10.1016/j.phytochem.2004.06.037.

Panthong, K, Pongcharoen, W., Phongpaichit, W., and Taylor, W.C., 2006. Tetraoxygenated Xanthones from The Fruit of Garcinia cowa. Phytochemistry 67, 999 -10043. DOI:10.1016/j.phytochem.2006.02.027.

Supriatno, Nurlelasari, Herlina, T., Harneti, D., Maharani, R., Hidayat, A.T., Mayanti, T., Supratman, U., Azmi, M.N., and Shiono, Y., 2018. A new limonoid from stem bark of Chisochetonpentandrus (Meliaceae). Natural Product Research 1-7. DOI: 10.1080/14786419.2018.1428600. 
Susanti, D., Amiroudin, Z.A.M.M.A., Rezalic, M.F., and Taher M., 2013. Friedelin and lanosterol from Garcinia prainiana stimulated glucose uptake and adipocytes differentiation in 3T3-L1 adipocytes. Natural Product Research 27(5), 417-424. DOI: $10.1080 / 14786419.2012 .725399$.

Xiang, T., Shibuya, M., Katsube, Y., Tsutsumi, T., Otsuka, M., Zhang, H., Masuda, K., and Ebizuka, Y., 2006. A New Triterpene Synthase from Arabidopsis thaliana Produces a Tricyclic Triterpene with Two Hydroxyl Groups. Organic Letters 8(13), 28352838. DOI: 10.1021/o1060973p. 